$11-2020$

\title{
Shared Indigenous and Crown Sovereignty: Modifying the State Model
}

Kent McNeil

Osgoode Hall Law School of York University, kmcneil@osgoode.yorku.ca

Follow this and additional works at: https://digitalcommons.osgoode.yorku.ca/scholarly_works

Part of the Indian and Aboriginal Law Commons

\section{Repository Citation}

McNeil, Kent, "Shared Indigenous and Crown Sovereignty: Modifying the State Model" (2020). Articles \& Book Chapters. 2815.

https://digitalcommons.osgoode.yorku.ca/scholarly_works/2815

This Article is brought to you for free and open access by the Faculty Scholarship at Osgoode Digital Commons. It has been accepted for inclusion in Articles \& Book Chapters by an authorized administrator of Osgoode Digital Commons. 


\title{
Shared Indigenous and Crown Sovereignty: Modifying the State Model
}

\author{
(C) Kent McNeil, ${ }^{*}$ Osgoode Hall Law School, November 2020
}

\begin{abstract}
When European nations colonized North America, their dealings with one another were based on the state model of territorial sovereignty. At the same time, they acknowledged the independence of the Indigenous nations and entered into nation-to-nation treaties with them, whereby sovereignty was to be shared. Consequently, the Westphalian concept of absolute state sovereignty has never applied in North America. While the European nations acquired sovereignty vis-à-vis one another in the international law system that they created, the Indigenous nations retained internal sovereignty and the right to continue governing themselves. This modified concept of state sovereignty has been acknowledged by the United States Supreme Court since the 1820 s and is gradually being accepted in Canada. It is consistent with, and even required by, the United Nations Declaration on the Rights of Indigenous Peoples, in particular that document's affirmation of the right of Indigenous peoples to self-determination and their right to internal self-government.
\end{abstract}

\section{Text}

The concept of sovereignty as we know it developed in Europe in the medieval period as the universalist claims to political authority of the Pope and the Holy Roman Emperor were challenged by the rulers of emerging nation-states and as the fragmented jurisdiction that characterized feudalism was replaced by more centralized authority. ${ }^{1}$ This new system of independent states that had been developing since at least the $12^{\text {th }}$ century was formally acknowledged by the Peace of Westphalia in $1648 .^{2}$ As theorized by Jean Bodin in Six Bookes of a Commonweale ${ }^{3}$ published in 1576 , sovereigns came to be viewed as having complete political authority within their territories and as being equal in their relations with one another. This absolutist conception of sovereignty held sway up until the late twentieth century, when it began to be weakened by, among other things, creation of the European Union and acceptance of the Responsibility to Protect, whereby states have an obligation to intervene in the internal affairs of other states that engage in genocide and other crimes against humanity. ${ }^{4}$

\footnotetext{
${ }^{*}$ I am grateful to Kathy Simo and Brian Slattery for reading and providing helpful feedback on a draft of this paper.

${ }^{1}$ See Sidney Painter, The Rise of the Feudal Monarchies (Ithaca: Cornell University Press, 1951); Hendrik Spruyt, The Sovereign State and Its Competitors: An Analysis of Systems Change (Princeton: Princeton University Press, 1994); Martin van Creveld, The Rise and Decline of the State (Cambridge: Cambridge University Press, 1999), 59125; Stuart Elden, The Birth of Territory (Chicago: University of Chicago Press, 2013).

${ }^{2}$ See Leo Gross, "The Peace of Westphalia, 1648-1948" (1948) 42 Am. J. of Int'l L. 20; Benno Teschke, The Myth of 1648: Class, Geopolitics, and the Making of Modern International Relations (London: Verso, 2003); Stéphane Beaulac, The Power of Language in the Making of International Law: The Word Sovereignty in Bodin and Vattel and the Myth of Westphalia (Leiden: Martinus Nijhoff Publishers, 2004).

${ }^{3}$ Jean Bodin, Les six livres de la république, Richard Knolles trans., Kenneth Douglas McRae ed. (Cambridge MA: Harvard University Press 1962).

${ }^{4}$ The international community adopted the Responsibility to Protect at the 2005 World Summit of the United Nations. See United Nations Office on Genocide Prevention and the Responsibility to Protect, online: <https://www.un.org/en/genocideprevention/about-responsibility-to-protect.shtml>. Of course, globalization and
} 
Prior to European colonization, the Indigenous nations of North America were factually independent. Although socially and politically organized in vastly different ways than European states, they exercised jurisdictional control amounting to de facto sovereignty over their territories and peoples. Their political independence was acknowledged by France and Britain in particular, in part through the negotiation of treaties with them. ${ }^{5}$ At the same time, however, in their relations with one another the European nations tended to act as though North America was juridically vacant - terra nullius - insofar as territorial sovereignty was concerned. ${ }^{6}$ They made preposterous claims to vast regions scarcely even explored by them on the basis of discovery, papal grants, symbolic acts of possession, royal charters, and the like that did not take account of the presence and control of the Indigenous nations. ${ }^{7}$ The Europeans thus adopted a two-faced approach to colonization, acknowledging Indigenous sovereignty on the one hand and effectively denying it on the other, depending on whether they were dealing with Indigenous nations or fellow European nations. ${ }^{8}$ Eventually, of course, the European nations and their successors, the United States, Mexico and Canada, were able to extend their de facto sovereignty over all of North America. The European state system that became the basis for international law was applied, as it has been in the World generally (apart from oceans, seas, and Antarctica).

What, then, happened to the Indigenous sovereignty that pre-dated this state system? Did it disappear, or was it somehow taken into account and incorporated into the body politic of what became the United States and Canada? As these questions were addressed earlier and more explicitly in the United States, this paper begins with a discussion of how American jurisprudence modified the Westphalian model to make space for continuing Indigenous

corporate power have also been weakening state sovereignty: e.g. see Joel Bakan, The New Corporation: How "Good" Corporations Are Bad for Democracy (Allen Lane, 2020). On other factors undermining state authority, see Creveld, supra note 1 at 336-414; James A. Caporaso, "Changes in the Westphalian Order: Territory, Public Authority, and Sovereignty” (2000) 2:2 Int'l Stud. Rev. 1.

5 See W.J. Eccles, “Sovereignty-association, 1500-1783” (1984) 65:4 Can. Hist. Rev. 475; Cornelius J. Jaenen, "French Sovereignty and Native Nationhood during the French Régime", in J.R. Miller, ed., Sweet Promises: A Reader on Indian-White Relations in Canada (Toronto: University of Toronto Press, 1991), 19; Andrée Lajoie \& Pierre Verville, "Les Traités d'Alliance entre les Français et Les Premières Nations sous le Régime Français", in Andrée Lajoie, Jean-Maurice Brisson, Sylvio Normand \& Alain Bissonnette, eds., Le Statut Juridique des Peuples Autochtones au Québec et le Pluralisme (Québec: Les Editions Yvon Blais, 1996), 161; Michael Asch, ed., Aboriginal and Treaty Rights in Canada: Essays on Law, Equality, and Respect for Difference (Vancouver: UBC Press, 1997) [Asch, Aboriginal and Treaty Rights]; Michael Asch, On Being Here to Stay: Treaties and Aboriginal Rights in Canada (Toronto: University of Toronto Press, 2014) [Asch, On Being Here to Stay].

${ }^{6}$ However, European practice varied, depending on the time and place. Acknowledgement of Indigenous sovereignty in North America was more common early in the colonization process than later on: see Brian Slattery, “Did France Claim Canada upon 'Discovery'?”, in J.M. Bumsted, ed., Interpreting Canada's Past, vol. 1, Before Confederation (Toronto: Oxford University Press, 1986), 2-26; Michel Morin, L'Usurpation de la souveraineté autochtone: Le cas des peuples de la Nouvelle-France et des colonies anglaises de l'Amérique du Nord (Montréal: Boréal, 1997).

${ }^{7}$ See John Thomas Juricek, English Claims in North America to 1660: A Study in Legal and Constitutional History, Ph.D. dissertation, University of Chicago Department of History, 1970; Patricia Seed, Ceremonies of Possession in Europe's Conquest of the New World, 1492-1640 (Cambridge: Cambridge University Press, 1995); Brian Slattery, "Paper Empires: The Legal Dimensions of French and English Ventures in North America" in John McLaren, A.R. Buck \& Nancy E. Wright, eds., Despotic Dominion: Property Rights in British Settler Societies (Vancouver: UBC Press, 2005), 50-78.

${ }^{8}$ See Brian Slattery, “The Hidden Constitution: Aboriginal Rights in Canada" (1984) 32 Am. J. of Comp. L. 361, esp. at 361-63, 374-76. 
sovereignty. Turning to Canada, I suggest that an equivalent modification is beginning to take place here, so a sharing of Indigenous and Crown sovereignty can be envisaged. International support for this development is provided by the United Nations Declaration on the Rights of Indigenous Peoples that Canada has pledged to implement.

\section{The United States}

The United States Supreme Court addressed the matter of the political status of the Indian nations or tribes (as they are still called in the US) in the 1820s and ' 30 s in three leading judgments delivered by Chief Justice John Marshall. In Johnson v. M'Intosh, ${ }^{9}$ he dealt with the validity of pre-American Revolution private purchases of Indian land north of the Ohio River where the British Crown claimed sovereignty. He found the purchases could not be upheld in American courts, mainly because the infamous doctrine of discovery, which he incorporated into American law from what he wrongly supposed to be a principle of international law, ${ }^{10}$ gave a discovering European nation the sole power of acquiring lands from the Indian nations by purchase or conquest. ${ }^{11}$ He also decided that the Royal Proclamation of 1763, issued by King George III, prevented purchases of Indian lands other than by the British Crown. He nonetheless thought that Indigenous sovereignty and land rights were only limited by British acquisition of sovereignty - they were not extinguished:

In the establishment of these relations, the rights of the original inhabitants were in no instance entirely disregarded; but were necessarily, to a considerable extent, impaired. They were admitted to be the rightful occupants of the soil, with a legal as well as just claim to retain possession of it, and to use it according to their own discretion; but their rights to complete sovereignty, as independent nations, were necessarily diminished, and their power to dispose of the soil at their own will, to whomsoever they pleased, was denied by the original fundamental principle, that discovery gave exclusive title to those who made it. ${ }^{12}$

But Marshall C.J. gave another reason for denying the enforceability of the private purchases in American courts that is even more revealing of the extent to which the Indian

\footnotetext{
98 Wheat. (21 U.S.) 543 (1823).

${ }^{10}$ Marshall C.J. thought all the colonizing European powers had agreed to this principle, but this was not the case: see works cited in note 7 supra and L. Oppenheim, International Law: A Treatise (London: Longmans, Green, 1905), vol. 1, 265; M.F. Lindley, The Acquisition and Government of Backward Territory in International Law (London: Longmans, Green \& Co, 1926); Julius Goebel, Jr., The Struggle for the Falkland Islands: A Study in Legal and Diplomatic History (1927, reissued Port Washington, NY: Kennikat Press, 1971), 47-119; Friedrich August Freiherr von der Heydte, "Discovery, Symbolic Annexation and Virtual Effectiveness in International Law" (1935) 29 Am. J. of Int'l L. 448.

${ }^{11}$ For critiques, see David E. Wilkins \& K. Tsianina Lomawaima, Uneven Ground: American Indian Sovereignty and Federal Law (Norman: University of Oklahoma Press, 2001), 19-63; Frank Pommersheim, Broken Landscape: Indians, Indian Tribes, and the Constitution (New York: Oxford University Press, 2009), 88-115; Robert J. Miller, et al., Discovering Indigenous Lands: The Doctrine of Discovery in the English Colonies (Oxford: Oxford University Press, 2010); Kent McNeil, "The Doctrine of Discovery Reconsidered: Reflecting on Robert J Miller, Jacinta Ruru, Larissa Behrendt, and Tracey Lindberg, Discovering Indigenous Lands: The Doctrine of Discovery in the English Colonies and Felix Hoehn, Reconciling Sovereignties: Aboriginal Nations and Canada" (2016) 53:2 Osgoode Hall Law Journal 699-728.

${ }^{12}$ Johnson v. M'Intosh, supra note 9 at 574 (emphasis added).
} 
nations retained aspects of their sovereignty. He said that purchases from those nations would be subject to their laws and,

[a]dmitting their power to change their laws or usages, ... if they choose to resume it [the grant], and make a different disposition of the land, the Courts of the United States cannot interpose for the protection of the title. The person who purchases lands from the Indians, within their territory, incorporates himself with them, so far as respects the property purchased; holds their title under their protection, and subject to their laws. If they annul the grant, we know of no tribunal which can revise and set aside the proceeding. ${ }^{13}$

When the nations in question subsequently signed treaties ceding the territory where the lands were located to the United States, the earlier purchases were necessarily annulled. ${ }^{14}$ It is therefore apparent that Marshall C.J. thought the Indian nations retained not only their own laws, but also the sovereign authority to alter those laws after British colonization.

Cherokee Nation v. Georgia, ${ }^{15}$ the second of the Marshall trilogy of Indian rights cases, was brought by the Cherokee Nation in the Supreme Court, which has original jurisdiction to decide cases in which a State is a party, including cases between "a State ... and foreign States". ${ }^{16}$ The Cherokee Nation sought "an injunction to restrain the state of Georgia from the execution of certain laws of that state, which, as is alleged, go directly to annihilate the Cherokees as a political society, and to seize, for the use of Georgia, the lands of the nation which have been assured to them by the United States in solemn treaties repeatedly made and still in force." 17 For the Supreme Court to have jurisdiction, the Cherokee Nation therefore had to be a "foreign State". Marshall C.J. had no difficulty finding the Cherokee Nation to be a state:

So much of the argument as was intended to prove the character of the Cherokees as a state, as a distinct political society, separated from others, capable of managing its own affairs and governing itself, has, in the opinion of a majority of the judges, been completely successful. They have been uniformly treated as a state from the settlement of our country. The numerous treaties made with them by the United States recognize them as a people capable of maintaining the relations of peace and war, [and] of being responsible in their political character for any violation of their engagements.... The acts of our government plainly recognize the Cherokee Nation as a state, and the courts are bound by those acts. ${ }^{18}$

A more difficult question was whether the Cherokee Nation is a foreign State. Noting the unique position of the Cherokees, Marshall C.J. observed that " $[\mathrm{t}]$ he condition of the Indians in relation to the United States is perhaps unlike that of any other two peoples in existence." 19

\footnotetext{
${ }^{13}$ Ibid. at 593 (emphasis added).

${ }^{14}$ Ibid. at 593-94.

155 Pet. (30 U.S.) 1 (1831) [Cherokee Nation].

${ }^{16}$ Constitution of the United States, Art. III, s.2(1)-(2).

${ }^{17}$ Cherokee Nation, supra note 15 at 15.

${ }^{18}$ Ibid. at 16.

${ }^{19}$ Ibid.
} 
While acknowledging that the Cherokees are aliens who do not owe allegiance to the United States, ${ }^{20}$ he said that the "Indian territory is admitted to compose part of the United States." $21 \mathrm{He}$ continued:

In all our intercourse with foreign nations, in our commercial regulations, in any attempt at intercourse between Indians and foreign nations, they are considered as within the jurisdictional limits of the United States, subject to many of those restraints which are imposed upon our own citizens. They acknowledge themselves in their treaties to be under the protection of the United States; they admit that the United States shall have the sole and exclusive right of regulating the trade with them, and managing all their affairs as they think proper. ${ }^{22}$

From this, we can see that, in the Supreme Court's opinion, the Cherokee and other Indian nations were regarded as residing within the territorial limits of the United States. Their external sovereignty had been lost because they could no longer trade or enter into other relations with foreign nations, as those matters were governed by the United States. Marshal C.J. confirmed this loss of external sovereignty by stating that "[ $\mathrm{t}]$ hey and their country are considered by foreign nations, as well as by ourselves, as being so completely under the sovereignty and dominion of the United States that any attempt to acquire their lands, or to form a political connexion with them, would be considered by all as an invasion of our territory and an act of hostility." 23 Consequently, the Indian nations, although states in the sense that they have retained political authority, are not foreign states, but rather "domestic dependent nations." 24 Marshall C.J. found further support for this conclusion in article I, section 8(3), of the Constitution, which provides Congress with the power to "regulate commerce with foreign nations, and among the several States, and with the Indian tribes." By designating the Indian tribes separately from foreign nations in this clause, the Constitutional Convention cannot, in his opinion, have meant to include them in the meaning of "foreign States" in article III, section 2(1), when describing the jurisdiction of the courts. ${ }^{25}$ As a result, the motion for an injunction was denied because the Court lacked jurisdiction under the Constitution to decide the case.

The third Indian rights case decided by the Marshall Court, Worcester v. Georgia ${ }^{26}$ also involved the Cherokee Nation. It resulted from the prosecution and conviction by the State of Georgia of an American missionary, Samuel Worcester of Vermont, for violating Georgia law by residing in Cherokee territory without a licence from the State. He appealed his conviction and sentence of four years of hard labour in a State penitentiary to the Supreme Court, which clearly had jurisdiction over this case. Worcester argued, among other things, that the law of Georgia

\footnotetext{
${ }^{20}$ Indians generally were only made US citizens in 1924 by an Act of Congress: A bill granting citizenship to Indians, and for other purposes, Act of June 2, 1924, 43 Stat. 253. Thereafter, those who are enrolled members of Indian nations have dual citizenship. See Nell Jessup Newton et al., eds., Cohen's Handbook of Federal Indian Law 2012 Edition (Newark NJ: LexisNexis, 2012), §14.01.

${ }^{21}$ Cherokee Nation, supra note 15 at 17.

${ }^{22} \mathrm{Ibid}$. at 17.

${ }^{23}$ Ibid. at $17-18$.

${ }^{24}$ Ibid.

${ }^{25} \mathrm{Ibid}$. at $18-20$.

${ }^{26} 6$ Pet. (31 U.S.) 513 (1832).
} 
under which he had been charged was unconstitutional because it was repugnant to treaties between the United States and the Cherokee Nation, by which the United States had acknowledged that the Cherokee are a sovereign nation with authority to govern themselves and everyone residing in their territory, free of any interference by State legislatures. The Supreme Court agreed and overturned the conviction.

In several key passages, Marshall C.J. provided further understanding of the status of the Indian nations and their relationship with the United States. He started with the factual observation that "America, separated from Europe by a wide ocean, was inhabited by a distinct people, divided into separate nations, independent of each other and of the rest of the world, having institutions of their own, and governing themselves by their own laws." 27 He affirmed the doctrine of discovery he had adopted in Johnson $v$. M'Intosh, but modified it by limiting it to regulation of the rights among the European nations who had agreed to it - it could not affect the rights of the Indian nations who were in already in possession and who had not agreed to it. ${ }^{28}$ Referring to the pre-American Revolution colonial period, he said:

Certain it is, that our history furnishes no example, from the first settlement of our country, of any attempt on the part of the crown to interfere with the internal affairs of the Indians, farther than to keep out the agents of foreign powers, who, as traders or otherwise, might seduce them into foreign alliances. The King ... purchased their alliance and dependence by subsidies; but never intruded into the interior of their affairs, or interfered with their self government, so far as respected themselves only. ${ }^{29}$

Thus, while Britain asserted its sovereignty over the Indian nations insofar as their external relations were concerned, it respected their internal sovereignty. Likewise, when the "United States succeeded to all the claims of Great Britain, both territorial and political", it made no attempt "to enlarge them." ${ }^{30}$ The American government continued to respect both the internal sovereignty and the land rights of the Indian nations:

From the commencement of our government, congress has passed acts to regulate trade and intercourse with the Indians; which treat them as nations, respect their rights, and manifest a firm purpose to afford that protection which treaties stipulate. All these acts ... manifestly consider the several Indian nations as distinct political communities, having territorial boundaries within which their authority is exclusive, and having a right to all the lands within those, which is not only acknowledged, but guarantied, by the United States. $^{31}$

In a passage summing up the status of the Indian nations, Marshall C.J. concluded:

\footnotetext{
${ }^{27}$ Ibid. at 542-43.

${ }^{28} \mathrm{Ibid}$. at 544. In the international law upon which Marshall C.J. relied, agreements are binding only on the parties: see Clipperton Island Case (1932), 26 A.J.I.L. 390 at 394; Lord [Arnold Duncan] McNair, The Law of Treaties (Oxford: Clarendon Press, 1961), 309-21; Malcolm N. Shaw, International Law, 7th ${ }^{\text {th }}$ ed. (Cambridge: Cambridge University Press, 2014), 672-74.

${ }^{29}$ Worcester v. Georgia, supra 26 at 547.

${ }^{30} \mathrm{Ibid}$. at 544.

${ }^{31} \mathrm{Ibid}$. at 556-57.
} 
The Indian nations had always been considered as distinct, independent political communities, retaining their original natural rights, as the undisputed possessors of the soil, from time immemorial, with the single exception of that imposed by irresistible power, which excluded them from intercourse with any other European potentate than the first discoverer of the coast of the particular region claimed: and this was a restriction which those European potentates imposed on themselves, as well as on the Indians. The very term "nation," so generally applied to them, means "a people distinct from others." ... The words "treaty" and "nation" are words of our own language, selected in our diplomatic and legislative proceedings, by ourselves, having each a definite and well understood meaning. We have applied them to Indians, as we have applied them to the other nations of the earth. They are applied to all in the same sense. ${ }^{32}$

Consequently, the laws of Georgia could not apply in Cherokee territory, as that would violate the treaty relationship between the Cherokee and the United States and impinge on the political authority of the Cherokee nation. Under the Constitution and laws of the United States, relations with the Cherokee are entirely under the jurisdiction of the federal government. ${ }^{33}$

The internal sovereignty of the Indian nations has been reaffirmed by the US Supreme Court on numerous occasions. ${ }^{34}$ As we have seen from Marshall C.J.'s judgments, American acknowledgement of this internal sovereignty was simply a continuation of the earlier policy of the British Crown. So during the very period when the Westphalian conception of absolute sovereignty came to dominate European political thought and international law, a different concept of shared sovereignty was being applied in North America. This concept continued under the federal system created by the US Constitution, which may have drawn inspiration from the Constitution of the Haudenosaunee (Iroquois) Confederacy. ${ }^{35}$ So in the United States, sovereignty is shared internally by the federal government, the Indian nations, and the States. However, the Supreme Court has subjected the internal sovereignty of the Indian nations to a severe limitation - it is subject to the plenary power of Congress and so can be restricted and even terminated at any time. ${ }^{36}$ As we shall see, the Canadian Parliament had the same power up

\footnotetext{
${ }^{32}$ Ibid. at 559-60.

33 Ibid. at 561.

${ }^{34}$ E.g., see Ex parte Crow Dog, 109 U.S. 556 at 560-62 (1883); United States v. Mazurie, 419 U.S. 544 at 557

(1975); Santa Clara Pueblo v. Martinez, 436 U.S. 49 (1978); United States v. Wheeler, 435 U.S. 313 at $322-24$ (1978); United States v. Lara, 541 U.S. 193 at 204-05 (2004) [Lara].
}

${ }^{35}$ Whether the Haudenosaunee example influenced the Founding Fathers is a matter of debate: e.g., compare Donald A. Grinde Jr. \& Bruce E. Johansen Exemplar of Liberty: Native America and the Evolution of Democracy (Los Angeles: American Indian Studies Center, University of California, 1991), with Philip A. Levy, "Exemplars of Taking Liberties: The Iroquois Influence Thesis and the Problem of Evidence” (1996) 53:3 William \& Mary Q. 588, and Samuel B. Payne Jr., "The Iroquois League, the Articles of Confederation, and the Constitution", ibid., 605. See Grinde \& Johansen's response, "Sauce for the Goose: Demand and Definitions for 'Proof' Regarding the Iroquois and Democracy", ibid., 621.

${ }^{36}$ E.g., see United States v. Kagama, 118 U.S. 375 (1886); Lone Wolf v. Hitchcock, 187 U.S. 553 (1903); Tee-HitTon Indians v. United States, 348 U.S. 272 (1955); Cotton Petroleum Corporation v. New Mexico, 490 U.S. 163 at 192 (1989); South Dakota v. Yankton Sioux Tribe, 522 U.S. 329 at 343 (1998). For confirmation of the plenary power doctrine in the 21st century, see Lara, supra note 34. For criticism, see Philip P. Frickey, "Domesticating Federal Indian Law" (1996) 81 Minn. L. Rev. 31; Robert N. Clinton, "There Is No Federal Supremacy Clause for Indian Tribes" (2002) 34 Ariz. St. L.J. 113; Robert A. Williams, Jr., Like a Loaded Weapon: The Rehnquist Court, 
until 1982, when it was removed by recognition of Aboriginal and treaty rights in the Constitution.

\section{Canada}

Although Canada, like the United States, is a federal state, the concept of shared sovereignty somehow got lost in the transition from British colonies to independent nation-state. Perhaps this was due to the concept of a unified Crown in which complete sovereignty is thought to be vested - the federal and provincial governments act on its behalf but, in theory, the Crown is a single legal entity that F.W. Maitland described as "a corporation sole." 37 Despite the unreality of this concept in a nation where the federal and provincial governments enter into contracts and sue one another in court, it has remained remarkably tenacious. ${ }^{38}$

Nonetheless, the notion of a single sovereign in Canada from which all governmental authority is derived is inconsistent with our history. From the outset of colonization, the French and British entered into treaties with the Indigenous peoples that acknowledged their political authority, a process that continued up to the 1920s, was renewed in the 1970s, and continues to this day. ${ }^{39}$ Although France and Britain claimed sovereignty vis-à-vis other European nations over the territory now known as Canada, they realized that their relations with the Indigenous nations were a separate matter, governed in part by Indigenous laws and protocols. ${ }^{40}$ In 1664 , the British entered into the Two-Row-Wampum (Kaswehntha or Guswhenta) Treaty with the Haudenosaunee at Albany, by which they agreed to respect each other's independence. ${ }^{41}$ In 1701, France negotiated a treaty of peace and alliance with forty sovereign Indigenous nations, an event that historian Gilles Havard describes as "a triumph for Amerindian diplomatic customs." 42 In 1764, after the British Crown acquired New France and issued the Royal Proclamation of 1763, Sir William Johnson, the Superintendent of Indian Affairs for the Britain's northern district, met with numerous Indigenous nations at Niagara, where he read the Proclamation and negotiated a treaty that respected their protocols and, among other things,

Indian Rights, and the Legal History of Racism in America (Minneapolis: University of Minnesota Press, 2005), 7183. On termination, see Donald L. Fixico, Termination and Relocation: Federal Indian Policy, 1945-1960 (Albuquerque: University of New Mexico Press, 1986).

${ }^{37}$ F.W. Maitland, "The Crown as Corporation Sole" (1901) 17 L.Q.R. 131.

${ }^{38}$ For recent affirmation of the unity of the Crown, see Grassy Narrows First Nation v. Ontario (Natural Resources), [2014] 2 S.C.R. 447. For criticism, see Kent McNeil, "The Obsolete Theory of Crown Unity in Canada and Its Relevance to Indigenous Claims" (2015) 20 Rev. of Const'l Stud. 1.

${ }^{39}$ See James (Sa'ke'j) Youngblood Henderson, Treaty Rights in the Constitution of Canada (Toronto: Thomson Carswell, 2007); Joshua Ben David Nichols, "A Narrowing Field of View: An Investigation into the Relationship Between the Principles of Treaty Interpretation and the Conceptual Framework of Canadian Federalism" (2019) 56:2 Osgoode Hall L.J. 350-95. Canada inaugurated the modern treaty process in 1973 by creating the comprehensive land claims policy after the Supreme Court's decision in Calder v. Attorney-General of British Columbia, [1973] S.C.R. 313.

${ }^{40}$ In addition to the sources cited supra in notes 6 and 7, see Canada, Report of the Royal Commission on Aboriginal Peoples, vol. 1, Looking Forward, Looking Back (Ottawa: Canada Communication Group, 1996), 99-136; Aimée Craft, Breathing Life into the Stone Fort Treaty: An Anishinabe Understanding of Treaty One (Saskatoon: Purich Publishing, 2013), especially 31-36, 66-83.

${ }^{41}$ See Henderson, supra note 39 at 158-61.

${ }^{42}$ Gilles Havard, The Great Peace of Montreal of 1701: French-Native Diplomacy in the Seventeenth Century, translated by Phyllis Aronoff \& Howard Scott (Montreal \& Kingston: McGill-Queen's University Press, 2001$), 182$. 
"gave treaty recognition to the nation-to-nation relationship between the First Nations and the British Crown." 43

In 1990 in $R$. v. Sioui, ${ }^{44}$ the Supreme Court of Canada likewise acknowledged the independence of the Indigenous nations in what is now Eastern Canada during the colonial period when France and Britain claimed sovereignty vis-à-vis Europeans. For a unanimous Court, Justice Lamer (as he then was) said:

The mother countries did everything in their power to secure the alliance of each Indian nation and to encourage nations allied with the enemy to change sides. When these efforts met with success, they were incorporated in treaties of alliance or neutrality. This clearly indicates that the Indian nations were regarded in their relations with the European nations which occupied North America as independent nations. The papers of Sir William Johnson (The Papers of Sir William Johnson, 14 vol.), who was in charge of Indian affairs in British North America, demonstrate the recognition by Great Britain that nation-to-nation relations had to be conducted with the North American Indians. ${ }^{45}$

Lamer J. then quoted with approval a passage from in Worcester v. Georgia where the Chief Justice Marshall had said: "Such was the policy of Great Britain towards the Indian nations inhabiting the territory from which she excluded all other Europeans; such her claims, and such her practical exposition of the charters she had granted: she considered them as nations capable of maintaining the relations of peace and war; of governing themselves, under her protection; and she made treaties with them, the obligation of which she acknowledged."46 So although Britain excluded other European nations from the territories it claimed, it still considered the Indigenous peoples inhabiting these territories as nations that governed themselves. Moreover, when Britain accepted the French Capitulation of Montreal in 1760, that "was fundamentally an agreement between the French and the British which in no way prevented independent agreements between the British and the Indian nations, whether allies of the French or of the British, being concluded or continuing to exist." ${ }^{47}$ In other words, treaties with France only governed relations with that nation. "It would be contrary to the general principles of law," Lamer J. said, "for an agreement concluded between the English and the French to extinguish a treaty concluded between the English and the Hurons."48 Treaties with the Indigenous nations thus operated in a separate realm - they created nation-to-nation relationships that were not affected by diplomatic dealings between European nations.

Remarkably, one week after deciding $R$. v. Sioui, the Supreme Court delivered its unanimous judgment in $R$. v. Sparrow, in which it declared that "there was from the outset never

\footnotetext{
${ }^{43}$ Chippewas of Sarnia Band v. Canada (Attorney General), 51 O.R. (3d) 641 at para. 56. See John Borrows, "Wampum at Niagara: The Royal Proclamation, Canadian Legal History, and Self-Government", in Asch, Aboriginal and Treaty Rights, supra note 6 at 155.

44 [1990] 1 S.C.R. 1025.

${ }^{45}$ Ibid. at 1053.

${ }^{46}$ Ibid. at 1054, quoting Worcester v. Georgia, supra note 26 at 548-49 (Lamer J.'s emphasis).

${ }^{47}$ R. v. Sioui, supra note 44 at 1063.

${ }^{48}$ Ibid.
} 
any doubt that sovereignty and legislative power ... vested in the Crown". ${ }^{49}$ The Sparrow case involved the fishing rights of the Musqueam in British Columbia, where relations between the Indigenous peoples and the British were different from Eastern Canada. British sovereignty was asserted much later in British Columbia and treaties were not negotiated there, apart from the fourteen Douglas Treaties in the 1850s, involving small areas of Vancouver Island, and Treaty 8 in 1899, extending into the northeast of the province. Another difference was that the Indigenous peoples in what is now British Columbia were each smaller in population and more isolated geographically from one another than the Mi'kmaq, Haudenosaunee, Huron, Anishinaabe, and other eastern Indigenous peoples, so they did not pose a military threat to the British, either on their own or as allies of France, Britain's colonial rival in the East. The British apparently thought they could simply assert sovereignty over the Indigenous peoples west of the Rocky Mountains, and only entered into treaties with a few of them on Vancouver Island to acquire lands for settlement. The Supreme Court apparently agreed, given the statement in Sparrow that the Crown acquired sovereignty "at the outset" (which we now know was in 1846 when a bilateral treaty with the United States "conclusively established" British sovereignty ${ }^{50}$ ), even over the territories of the Gitxsan and Wet'suwet'en, far to the north of the international boundary along $49^{\text {th }}$ parallel in a region where the British were certainly not in effective occupation or control at the time.

How could Britain have acquired sovereignty over all of British Columbia in 1846 when its occupation and control was limited to small areas around isolated trading posts (e.g. Fort Langley and Fort Victoria) operated by the Hudson's Bay Company, posts that were few and far between and located mainly in the southern part of the territory ${ }^{51}$ Britain obviously did not have de facto sovereignty over the rest of the province, as that would have required effective control and the exercise of government functions. Its assertion of sovereignty was at best notional - it operated only at some abstract level and would not even have provided Britain with de jure sovereignty in the international law of the time. ${ }^{52}$

More recently, the Supreme Court has begun to exhibit some discomfort with the notion that the Crown could acquire sovereignty by mere assertion, confirmed by a treaty with the United States. In two decisions released simultaneously in 2004, Haida Nation v. British

\footnotetext{
49 [1990] 1 S.C.R. 1075 at 1103 [Sparrow].

${ }^{50}$ Delgamuukw v. British Columbia, [1997] 3 S.C.R. 1010 at para. 145 [Delgamuukw], relying on the 1846 Oregon Boundary Treaty that created the international boundary between British and American territories in the Pacific Northwest.

${ }^{51}$ See Derek Hayes, Historical Atlas of British Columbia and the Pacific Northwest (Vancouver, BC: Cavendish Books, 1999), 112-13, 125-27.

${ }^{52}$ See Island of Palmas Case, (1928) 2 R.I.A.A. 829; Legal Status of Eastern Greenland Case (1933), 2 P.C.I.J., Series A/B, No 43; Minquiers and Ecrehos Case, 1953 I.C.J.R. 47; Travers Twiss, The Law of Nations Considered as Independent Political Communities (Oxford: Clarendon Press, 1884), 196-211; L. Oppenheim, International Law: A Treatise (London: Longmans, Green, 1905), vol. 1, 275-80; M.F. Lindley, The Acquisition and Government of Backward Territory in International Law (London: Longmans, Green \& Co, 1926), 139-51. On the distinction between de facto and de jure sovereignty, see Kent McNeil, "Indigenous and Crown Sovereignty in Canada", in Michael Asch, John Borrows \& James Tully, eds., Resurgence and Reconciliation: Indigenous-Settler Relations and Earth Teachings (Toronto: University of Toronto Press, 2018), 293 at 301-02.
} 
Columbia (Minister of Forests) ${ }^{53}$ and Taku River Tlingit First Nation v. British Columbia (Project Assessment Director), 54 the Court, for the first time, acknowledged "pre-existing Aboriginal sovereignty", referred to Crown sovereignty as "de facto", and said that the promise of rights recognition in section 35 of the Constitution Act, 1982 "is realized and sovereignty claims reconciled through the process of honourable negotiation." 55 But if the Indigenous nations of British Columbia were sovereign prior to Britain's assertion of sovereignty in $1846,{ }^{56}$ how could the Crown have acquired sovereignty over them and their territories without conquest and without treaties with them that recognized Crown sovereignty ${ }^{57}$ A possible international law answer is prescription, which involves the peaceful exercise of de facto sovereignty for a sufficiently long time, but apparently de jure sovereignty could only be acquired by prescription if the prior sovereigns acquiesced, which the Indigenous nations have not. Moreover, prescription could not have applied in 1846 because the Crown's exercise of sovereignty did not even commence over most of the province until many years later. ${ }^{58}$

It is thus apparent that the Supreme Court has created quite a muddle for itself by acknowledging pre-existing Indigenous sovereignty while continuing to accept 1846 as the time of Crown assertion of sovereignty in British Columbia. ${ }^{59}$ A more accurate understanding of the legal history would be to accept that the Oregon Boundary Treaty of 1846 only settled the territorial claims of Britain and the United States in relation to one another. Given that the Indigenous nations were sovereign, that bilateral treaty could not have affected their territorial rights because they were not parties to it. ${ }^{60}$ Crown sovereignty over British Columbia was not acquired by that treaty; instead, the Crown gradually extended its sovereignty by exercising de facto jurisdiction and control over the province. The Supreme Court acknowledged in Haida Nation and Taku River that the Crown's sovereignty is de facto. However, due to the act of state

\footnotetext{
53 [2004] 3 S.C.R. 511 [Haida Nation].

54 [2004] 3 S.C.R. 550 [Taku River].

${ }^{55}$ Haida Nation, supra note 55 at para 20; Taku River, supra note 54 at para 42. Section 35(1) of the Constitution Act, 1982, being Sch. B to the Canada Act 1982 (U.K.) 1982. c. 11, provides: "The existing aboriginal and treaty rights of the aboriginal peoples of Canada are hereby recognized and affirmed." The pre-existing sovereignty of the Indigenous nations was reaffirmed in Manitoba Metis Federation Inc. v. Canada (Attorney General), [2013] 1 S.C.R. 623 at para. 67, and Mikisew Cree First Nation v. Canada (Governor General in Council), [2018] 2 S.C.R. 765 at para. 21.

56 This date for Crown assertion of sovereignty was confirmed, after Haida Nation and Taku River, supra notes 53 and 54, in Tsilhqot'in Nation v. British Columbia, [2014] 2 S.C.R. 257 at para. 60 [Tsilhqot'in Nation].

57 The Supreme Court acknowledged in Haida Nation, supra note 53 at para. 25, that the Indigenous peoples had never been conquered.

${ }^{58}$ On prescription, see D.H.N. Johnson, “Acquisitive Prescription in International Law” (1950) 27 Brit. Yb of Int'l L. 332; R.Y. Jennings, The Acquisition of Territory in International Law (Manchester: Manchester University Press, 1963), 20-28; Yehuda Z. Blum, Historic Titles in International Law (The Hague: Martinus Nijhoff, 1997), 6-37; Shaw, supra note 28 at 364-66; Asch, On Being Here to Stay, supra note 6 at 38-41.

${ }^{59}$ Although the Court usually refers to "assertion" of sovereignty, assertion must result in acquisition of sovereignty by the Crown: see Delgamuukw, supra note 49 at para. 145, where acquisition of underlying title to land was said to accompany assertion of sovereignty, which was "conclusively established by the Oregon Boundary Treaty of $1846 . "$ ${ }^{60}$ See the authorities cited in note 28 supra and the quotations from $R$. v. Sioui accompanying notes 47 and 48 supra. This is consistent as well with Marshall C.J.'s opinion in Worcester v. Georgia that the international law doctrine of discovery could not affect the rights of the Indian nations because they were not party to the agreement that created it: see text accompanying note 28 supra.
} 
doctrine, the courts do not have the authority to question Crown sovereignty. ${ }^{61}$ They are obliged to accept its reality but lack jurisdiction to rule on its legality. Nonetheless, as we have seen, the Court in Haida Nation seems to have realized that Crown sovereignty would not be legitimate until it is reconciled with pre-existing Indigenous sovereignty through honourable negotiations leading to treaties. ${ }^{62}$

What, then, is the situation prior to the negotiation of treaties that reconcile sovereignties, which is still the situation in most of British Columbia? It cannot be that the Westphalian model of sovereignty applies to give the Crown complete sovereignty, as that would be inconsistent with historical reality and fundamental principles of justice and self-determination of peoples. ${ }^{63}$ In 1846, we have seen that Britain occupied only tiny bits of the province (Hudson's Bay Company posts) and exercised no jurisdiction whatsoever over the Indigenous peoples. Consequently, Indigenous law and governmental authority must have continued unabated - there was simply no other law and authority in place. In other words, Indigenous sovereignty was maintained, alongside Crown sovereignty that was limited to miniscule areas. Over the second half of the $19^{\text {th }}$ century, the Crown gradually extended its jurisdiction over most of province, acquiring de facto sovereignty, as the Supreme Court recognized in Haida Nation and Taku River. But this does not mean Indigenous sovereignty was entirely displaced. ${ }^{64}$ Despite infringements on their sovereignty by the application of provincial and federal laws, such as hunting and fishing laws and the Indian Act, ${ }^{65}$ Indigenous nations continued to govern themselves and follow their own laws, albeit clandestinely in many cases. ${ }^{66}$ In Campbell $v$.

\footnotetext{
${ }^{61}$ See Duff Development Co. v. Government of Kelantan, [1924] A.C. 797 (H.L); R. v. Kent Justices, [1967] 1 All E.R. 560 (Q.B.) at 564-65; Adams v. Adams, [1970] 3 All E.R. 572 (P.D.A.) at 583, 585; Mabo v. Queensland (1992), 175 C.L.R. 1 at 31-32, 78-79; W. Harrison Moore, Act of State in English Law (London: John Murray, 1906); Kenneth Roberts-Wray, Commonwealth and Colonial Law (London: Stevens \& Sons, 1966), 116.

${ }^{62}$ See Felix Hoehn, Reconciling Sovereignties: Aboriginal Nations and Canada (Saskatoon: University of Saskatchewan Native Law Centre, 2012); Brian Slattery, "Aboriginal Rights and the Honour of the Crown" (2005) 29 S.C.L.R. (2d) 433 at 437-38.

${ }^{63}$ See Nichols, supra note 39. On the application of fundamental principles of justice in this context, see Brian Slattery, "Aboriginal Sovereignty and Imperial Claims" (1991) 29 Osgoode Hall L.J. 681 at 696-700, arguing that "every human society whose members draw the essentials of life from territories in their possession (whether collectively or individually) has a right to these territories as against other societies and individuals" (at 697). The right of Indigenous peoples to self-determination is recognized by article 3 of the United Nations Declaration on the Rights of Indigenous Peoples, discussed below.

${ }^{64}$ See Royal Commission on Aboriginal Peoples, Partners in Confederation: Aboriginal Peoples, Self-Government, and the Constitution (Ottawa: Canada Communication Group, 1993).

${ }^{65}$ First enacted in 1876 , S.C. 1876 , c. 18.

${ }^{66}$ E.g., after the potlatch was banned in 1884, this governance practice continued clandestinely in many communities: see Arthur J. Ray, I Have Lived Here Since the World Began: An Illustrated History of Canada's Native Peoples (Toronto: Lester Publishing, 1996), 222-30. Regarding fishing, the Supreme Court held in Sparrow, supra note 49 at 1095-98, that even intensive federal regulation did not extinguish inherent Aboriginal rights to fish.
} 
British Columbia,${ }^{67}$ Justice Williamson decided that the Indigenous peoples' inherent right to govern themselves has continued and not been extinguished. ${ }^{68}$

So as both a practical and a legal matter, the Indigenous nations must have retained some of their sovereignty. As a result of Crown acquisition of sovereignty, they have no doubt lost their authority to engage in relations with foreign states - given that the international community acknowledges Crown sovereignty over Canada, Indigenous sovereignty is internal rather than external. How, then, is sovereignty shared internally? Federal and provincial powers are listed in sections 91 and 92 of the Constitution Act, 1867.69 But as decided by Williamson J. in Campbell, that Act did not exhaustively distribute governmental powers. ${ }^{70}$ The pre-existing governmental authority of the Indigenous peoples continued and was recognized and affirmed by section 35 of the Constitution Act, 1982. ${ }^{71}$ Unlike sections 91 and 92, that section does not enumerate the powers of Indigenous governments; instead, it provides constitutional space and protection for the inherent governmental authority that Indigenous nations have as a result of their pre-colonization sovereignty. As Chief Justice Marshall acknowledged in Johnson v. M'Intosh and Worcester v. Georgia, prior to European colonization that authority was complete because the Indigenous nations were sovereign. European assertions of sovereignty and the incorporation of the Indigenous peoples into the United States diminished their sovereignty so they could no longer interact with foreign states, but it did not take away their internal sovereignty. Likewise in Canada, the inherent right of the Indigenous peoples to govern themselves, while limited by the concept of sovereign incompatibility, ${ }^{72}$ has continued to this day.

However, because the Crown has sovereignty, Parliament and the provincial legislatures also have governmental authority over Indigenous territories. Their authority, as defined by sections 91 and 92, is concurrent with Indigenous governmental authority, so federal and provincial laws can apply in Indigenous territories, in the absence of conflict with Indigenous laws. In the event of conflict, Indigenous laws should prevail because Indigenous sovereignty is protected by section 35. For federal or provincial laws to prevail over Indigenous laws, the Crown would have to prove that, in the circumstances, this is a justifiable infringement in accordance with the test established by the Supreme Court in Sparrow, which requires proof of a

\footnotetext{
${ }^{67}$ [2000] 4 C.N.L.R. 1 (B.C.S.C.) [Campbell]. In House of Sga'nisim v. Canada (Attorney General), [2012] 2 C.N.L.R. 82 (B.C.S.C.), Smith J. followed this aspect of Campbell out of comity, but also held that governance provisions of the Nisga'a Final Agreement (ratified 2000), the validity of which was challenged in both these cases, could also be upheld as delegated authority. Smith's decision was upheld on appeal on the latter basis, without deciding the inherent right issue: [2013] 2 C.N.L.R. 226 (B.C.C.A.).

${ }^{68}$ See also Pastion v. Dene Tha' First Nation, [2018] 4 FCR 467 at paras. 8-14 [Pastion]; Dickson v. Vuntut Gwitchin First Nation, 2020 YKSC 22.

6930 \& 31 Vict, (U.K.), c.3.

${ }^{70}$ Campbell, supra note 67 at paras. 65-82. See also Joshua Ben David Nichols, A Reconciliation without Reflection: An Investigation into the Foundations of Aboriginal Law (Toronto: University of Toronto Press, 2020).

${ }^{71}$ Campbell, supra note 67 at paras. 85-143. Section 35(1) is quoted in note 55 supra.

${ }^{72}$ See Mitchell v. M.N.R., [2001] 1 S.C.R. 911, per McLachlin C.J. at para. 10, Binnie J. at paras. 66-174. Justice Binnie, writing a minority judgment for himself and Major J., acknowledged that sovereignty in Canada could be shared between the Crown and Indigenous peoples, but viewed control over borders as so essential to Canada that any Indigenous rights inconsistent with that control would be incompatible with Crown sovereignty.
} 
valid legislative objective and respect for the Crown's fiduciary obligations towards the Indigenous peoples. ${ }^{73}$

Section 35 has resulted in a major shift in Canadian constitutional law. Prior to its enactment, Parliament enjoyed complete legislative authority over Indigenous peoples and their rights, ${ }^{74}$ equivalent to the plenary power of Congress in the United States. Since 1982, the rights recognized and affirmed by that section can no longer be extinguished unilaterally, even by Parliament, ${ }^{75}$ and infringement requires justification, which the Crown, as far as I know, has only been able to succeed in proving in one instance. ${ }^{76}$ The shared sovereignty that pre-dated section 35 has thus been constitutionalized, providing the Indigenous peoples with substantial protection for their governmental authority. ${ }^{77}$

\section{The United Nations Declaration on the Rights of Indigenous Peoples}

The UN General Assembly adopted the United Nations Declaration on the Rights of Indigenous Peoples (Declaration) on September 13, 2007. ${ }^{78}$ Although the United States and Canada initially voted against the Declaration, in 2010 President Obama announced that the United States would support it, and Canada in the same year provided weak acceptance. The Trudeau government went further in 2016 by endorsing it without qualification and promising to implement it.

Several articles in the Declaration are relevant to our discussion because they appear to endorse the concept of shared sovereignty. Article 3 states that "Indigenous peoples have the right to self-determination. By virtue of that right they freely determine their political status and freely pursue their economic, social and cultural development." The right to "freely determine their political status" must mean that they have the right to govern themselves. This is explicitly confirmed in article 4: "Indigenous peoples, in exercising their right to self-determination, have the right to autonomy or self-government in matters relating to their internal and local affairs, as well as ways and means for financing their autonomous functions." Article 5 provides in part that "Indigenous peoples have the right to maintain and strengthen their distinct political, legal, economic, social and cultural institutions" (this is repeated in article 20, with slightly different wording, with "develop" in place of "strengthen"). This implies that, if the authority of their political institutions has been restricted, their right to self-determination includes the right to re-

\footnotetext{
${ }^{73}$ For further discussion, see Kent McNeil, "The Jurisdiction of Inherent Right Aboriginal Governments" (West Vancouver: National Centre for First Nations Governance, 2007), online: Osgoode Digital Commons and <http://fngovernance.org/ncfng_research/kent_moneil.pdf $>$.

${ }^{74}$ See R. v. Sikyea, [1964] S.C.R. 642; R. v. George, [1966] S.C.R. 267; Kruger v. The Queen, [1978] 1 S.C.R. 104 at 111-12; R. v. Derriksan (1976), 71 D.L.R. (3d) 159.

${ }^{75}$ R. v. Van der Peet, [1996] 2 S.C.R. 507 at para. 28; Mitchell v. MNR, supra note 71 at para. 11.

${ }^{76}$ R. v. Constant; R. v. Goulet, [2003] 2 C.N.L.R. 240 (Que. C.A.), leave to appeal dismissed, S.C.C., 28 August 2003 , involving prohibition of use of live bait for fishing.

77 The Parliament of Canada, in An Act respecting First Nations, Inuit and Métis children, youth and families, S.C. 2019, c. 24, in force as of 1 January 2020, acknowledged the constitutional authority of the Indigenous peoples to govern themselves. Section 18(1) provides: "The inherent right of self-government recognized and affirmed by section 35 of the Constitution Act, 1982 includes jurisdiction in relation to child and family services, including legislative authority in relation to those services and authority to administer and enforce laws made under that legislative authority."

${ }^{78}$ Online: <https://undocs.org/A/RES/61/295>.
} 
assert their governance authority. Article 18 states: "Indigenous peoples have the right to participate in decision-making in matters which would affect their rights, through representatives chosen by themselves in accordance with their own procedures, as well as to maintain and develop their own indigenous decision-making institutions." These representative institutions are obviously governmental in nature, as they have authority to participate in decision-making in relation to rights. Article 33(2) provides that "Indigenous peoples have the right to determine the structures and to select the membership of their institutions in accordance with their own procedures." "Institutions" in this article must include "political institutions" in accordance with articles 5 and 20 (above). Article 34 acknowledges the right of Indigenous peoples "to promote, develop and maintain their ... judicial systems and customs", thereby recognizing that they have governance authority in relation to enforcing their own laws. ${ }^{79}$ Article 37(1) provides that "Indigenous peoples have the right to the recognition, observance and enforcement of treaties, agreements and other constructive arrangements concluded with States or their successors and to have States honour and respect such treaties, agreements and other constructive arrangements." As we have seen, early treaties in what are now the United States and Canada acknowledged Indigenous sovereignty and created nation-to-nation relationships. Articles 41 and 42 impose obligations on the United Nations to contribute to the realization of the Declaration's provisions and to promote respect for the rights contained therein.

Taken as a whole, the Declaration's provisions provide strong acknowledgment of the right of Indigenous peoples to govern themselves, but only within the confines of the state that encompasses them. This is made clear at the end of the Declaration in article 46, which provides in part: "Nothing in this Declaration may be ... construed as authorizing or encouraging any action which would dismember or impair, totally or in part, the territorial integrity or political unity of sovereign and independent States."

The Declaration is consistent with the American concept of shared sovereignty (though probably not with the plenary power of Congress) that has been accepted by the Supreme Court ever since Chief Justice Marshall's decisions in the 1820s and '30s. Justifiable infringement aside, ${ }^{80}$ it is also consistent with the interpretation of Canadian constitutional law presented in this paper. The Declaration thus provides international confirmation of the continuing internal sovereignty of the Indigenous peoples in North America.

\section{Conclusion}

\footnotetext{
${ }^{79}$ In Pastion, supra note 68 at para. 10, Grammond J. cited Article 34 in support of Indigenous peoples' authority to make their own laws.

${ }^{80}$ Article 46(2) of the Declaration provides in part: "The exercise of the rights set forth in this Declaration shall be subject only to such limitations as are determined by law and in accordance with international human rights obligations. Any such limitations shall be non-discriminatory and strictly necessary solely for the purpose of securing due recognition and respect for the rights and freedoms of others and for meeting the just and most compelling requirements of a democratic society." On whether this provision allows for justification of infringement of Declaration rights in much the same way as the Supreme Court has allowed for justifiable infringement of section 35 rights, see Ryan Beaton, “Articles 27 and 46(2): UNDRIP Signposts Pointing beyond the Justifiable Infringement Morass of Section 35", in UNDRIP Implementation: More reflections on the Braiding of International, Domestic and Indigenous Laws, Special Report (Waterloo, ON: Centre for International Governance Innovation, 2018 ), 111.
} 
The concept of absolute state sovereignty is gradually being eroded as Indigenous nations in North America challenge its imposition on them and demand acknowledgement of their sovereignty. However, with rare exceptions - the Haudenosaunee Confederacy is one - they are not asserting their independence from the United States or Canada. Instead, they are generally willing to share sovereignty with the governments of these states.

Although the United States Supreme Court acknowledged internal Indigenous sovereignty early on, the Court's later invention of congressional plenary power over the Indian nations has diminished Indigenous sovereignty by making it vulnerable to the legislative will of Congress. Fortunately, Canada moved away from parliamentary supremacy over the Indigenous peoples when section 35 was included in the Constitution in 1982, though the justifiable infringement doctrine does provide a way for legislatures to impinge on Indigenous sovereignty in some situations. Nonetheless, shared sovereignty is now a constitutional reality in Canada.

The Westphalian model of complete state sovereignty has never applied in North America, as is evident from the nation-to-nation relationships developed with the Indigenous peoples by treaty and other dealings. ${ }^{81}$ The United Nations, by adopting the Declaration on the Rights of Indigenous Peoples, has acknowledged that internal sovereignty has to be shared with Indigenous peoples. The challenge now is to get states to take this concept of shared sovereignty seriously and fully implement the Declaration.

\footnotetext{
${ }^{81}$ See Joshua Ben David Nichols, "A Narrowing Field of View: An Investigation into the Relationship Between the Principles of Treaty Interpretation and the Conceptual Framework of Canadian Federalism" (2019) 56:2 Osgoode Hall L.J. 350-95.
} 